\title{
Research on Quantitative Evaluation of Post Safety Competency of Port Operators
}

\author{
Hang Jin ${ }^{1, \mathrm{a}}$, Guodong Meng ${ }^{2, \mathrm{~b}}$, Yanhua Hu*3,c , Pengyu Jia ${ }^{4, \mathrm{~d}}$, Wenxin Jiang ${ }^{5, \mathrm{e}}$, Shuifen Zhan ${ }^{6, \mathrm{f}}$ \\ ${ }^{1}$ Tianjin Research Institute for Water Transport Engineering, Ministry of transport, Tianjin, China \\ ${ }^{2}$ Tianjin Dong Fang Tai Rui Technology Co. Ltd, Tianjin, China \\ ${ }^{3}$ Tianjin Research Institute for Water Transport Engineering, Ministry of transport, Tianjin, China \\ ${ }^{4}$ Tianjin Research Institute for Water Transport Engineering, Ministry of transport, Tianjin, China \\ ${ }^{5}$ Tianjin Research Institute for Water Transport Engineering, Ministry of transport, Tianjin, China \\ ${ }^{6}$ Tianjin Research Institute for Water Transport Engineering, Ministry of transport, Tianjin, China
}

\begin{abstract}
This study took one subsidiary company of a certain domestic port group as a sample. Through job hazard source analysis, job demand analysis, open questionnaire survey, literature review, etc., the characteristics of post safety competency were collected and analyzed, and through statistical analysis of the sample data of the target positions, the reliability and validity analysis of the principal component analysis of the job competency characteristic elements were carried out to optimize and determine the theoretical model and its core characteristic elements, so as to establish the framework of the safety competency characteristic model of the target positions and form the post safety competency evaluation index system. Based on the objective weighting theory analysis method of system dynamics, the entropy weight of each level assessment index was calculated by using the information entropy of key post sample population, and then the weight of each level assessment index was corrected by the entropy value. According to the security requirements of mooring line workers, this paper carried out the theory of multilevel fuzzy comprehensive evaluation, the matrix model of multi-level safety fuzzy evaluation was established, and the fuzzy comprehensive evaluation was used for the third-level index, second-level index and first-level index successively, so that the comprehensive evaluation result of each level can be obtained respectively, and port operators' post safety competency can also be quantitatively evaluated.
\end{abstract}

\section{Introduction}

Due to the high degree of continuity and complexity of port production, it is more dangerous and more insecure than the general industry. According to the analysis of a large number of accident cases, more than $80 \%$ of accidents in port enterprises were caused by human fault. With the development of process equipment, the requirements for all aspects of the quality and abilities of the operators in key positions have become increasingly important. It can be said that the operators in key positions have become the most direct, terminal, and most important link in the accident chain.

Therefore, to ensure safe and orderly production of key positions and effectively manage the safety of operators in key positions, a post safety competency model and evaluation index system should be established and optimized. For the research on post safety competency model, Boyatzis [1-2] first proposed a general competency model for managers, and believed that the competencies in target and action management, leadership, human resource management, technical education and special knowledge guidance of subordinates were the necessary conditions to achieve excellent management performance. Yan [3] et al.

a549594262@qq.com, ${ }^{b}$ mengguodong@tk-aq.com, ${ }^{\text {c* }}$ huyanhua@tk-aq.com

djiapengyu@tk-aq.com, ${ }^{\mathrm{e} j i a n g w e n x i n @ t k-a q . c o m},{ }^{\mathrm{f}} \mathrm{zsf} @ \mathrm{tk}$-aq.com

(c) The Authors, published by EDP Sciences. This is an open access article distributed under the terms of the Creative Commons Attribution License 4.0

(http://creativecommons.org/licenses/by/4.0/) conducted research on the capabilities of safety management personnel from the perspective of education, age, experience, and training. In addition to the above dimensions, Chen Fang, Sadeghi et al. [4-12] established a safety management personnel competency model based on knowledge, skills, ideas and personal characteristics. Chen et al. [13] constructed a competency model for safety management personnel of civil aviation operating units, and proposed 7 first-level core indicators and 29 secondlevel element indicators. Li et al. [14-21] established a safety competency model for special coal mine operations personnel in view of the accident-prone phenomenon of some individual miners. However, there is a big difference between the above-mentioned research objects and the post safety competency of port operators.

In summary, it is easy to find that for the safety assessment and skill improvement of job operators, foreign scholars mostly start from the perspective of security technology, safety technology and related safety protection measures, and only make suggestions for operators as an independent individual; domestic scholars mainly put forward suggestions from the perspectives of laws, rules and regulations, standards and norms, and psychology. Therefore, conducting integrated and 
comprehensive research of port operations personnel post safety competence characteristics from the perspective of safety behavior, and building a post competency model and its safety evaluation index system of technology, are important methods and effective ways to improve the safety skills of operators and the status quo of port safety production and realize the optimal match between operators and posts.

\section{Job safety accomplishment and competence model}

This research collected the characteristic elements of job safety competence through analysis of hazards and risk factors, job requirements, job key control nodes, and open questionnaire survey, in combination with literature review, interview method, and case analysis method. Through investigation and statistical analysis, we have fully understood the job safety competency characteristic elements and key situations or safety performance indicators considered by the target post operators, organized and formed 50 job safety competency characteristic elements, and verified and compiled the "Port Operation Personnel Safety Competency Questionnaire", as shown in Table 1.

By further optimizing the theoretical model and its core characteristic elements through the data statistics of the sample population of key positions, SPSS principal component analysis, reliability and validity analysis, etc., we identified key behavior and qualities, and then established the target position safety competency characteristic model framework, and formed a post safety competency evaluation index system.

Table1. Questionnaire on post safety competency of port operators

\begin{tabular}{|c|c|l|l|l|l|l|}
\hline \multirow{2}{*}{ No. } & \multirow{2}{*}{ Safety Competency Features } & \multicolumn{5}{|c|}{ Importance to safety and competence at work } \\
\cline { 3 - 6 } & & $\begin{array}{c}\text { Total } \\
\text { unimportant }\end{array}$ & Unimportant & $\begin{array}{c}\text { Generally } \\
\text { important }\end{array}$ & Important & $\begin{array}{c}\text { Very } \\
\text { important }\end{array}$ \\
\hline 1 & $\begin{array}{c}\text { Good health, able to bear the } \\
\text { labor intensity of post }\end{array}$ & & & & \\
\hline 2 & Highly educated & & & & & \\
\hline 3 & $\begin{array}{c}\text { Have clear career plan, and } \\
\text { career goals }\end{array}$ & & & & & \\
\hline 4 & $\begin{array}{c}\text { Master the operation skills } \\
\text { required for the post, and be } \\
\text { skilled }\end{array}$ & & & & & \\
\hline 5 & $\begin{array}{c}\text { Master the theoretical } \\
\text { knowledge required for the job }\end{array}$ & & & & & \\
\hline$\ldots$ & $\quad \ldots$ & & & & & \\
\hline
\end{tabular}

\section{Construction of technical index system for post safety competency evaluation}

\subsection{Sample data collection and analysis of the importance of the characteristic elements of job safety competence}

The tool used in this section is the "Questionnaire on Safety Competency of Port Operators", which was compiled after discussion and verification. The statistical method was to carry out statistical analysis and exploratory factor analysis on the collected effective data, and the statistical software used was SPSS 17.0.

The subject of the investigation came from the operators of a dangerous cargo enterprise of a port group. The specific information is shown in the table below. A total of 308 questionnaires were issued and 308 were returned, of which 281 were valid questionnaires. The response rate of the questionnaires was $100 \%$, and the response rate of the valid questionnaires was $91.2 \%$.

According to the description and statistics of the port operator's job safety competency questionnaire $(n=281$ persons), the items with an average score of 4.0 or more (i.e. important and very important) (full score of single item is 5.0) were further analyzed and 33 items were retained. According to the arrangement chart of primary and secondary factors, the cumulative percentage of $70 \%$ was used as the standard to define first-level and secondlevel indicators, and 23 core key items for port operator job safety competencies were determined. The results are shown in Table 2.

\subsection{Principal component analysis of job safety competencies of port operators}

The statistical results were analyzed first. After t-test analysis, the values of 23 core items (characteristic elements) have reached a significant statistical level $(p<0.001)$, indicating that the 23 items of the job safety competency questionnaire were all discriminating, which can identify the degree of response of different subjects.

Principal component analysis was performed on these 23 characteristic elements. According to the result of factor analysis, the KMO value (Kaiser Meyer Olkin) was 0.864, and the value of Bartlett's sphere test was 1244.886 (253 degrees of freedom), reaching a significant statistical level $(\mathrm{p}<0.001)$, and indicating that there are common factors among the correlation matrices representing data samples, which are suitable for factor analysis. The gravel diagram is shown in Figure 1. 


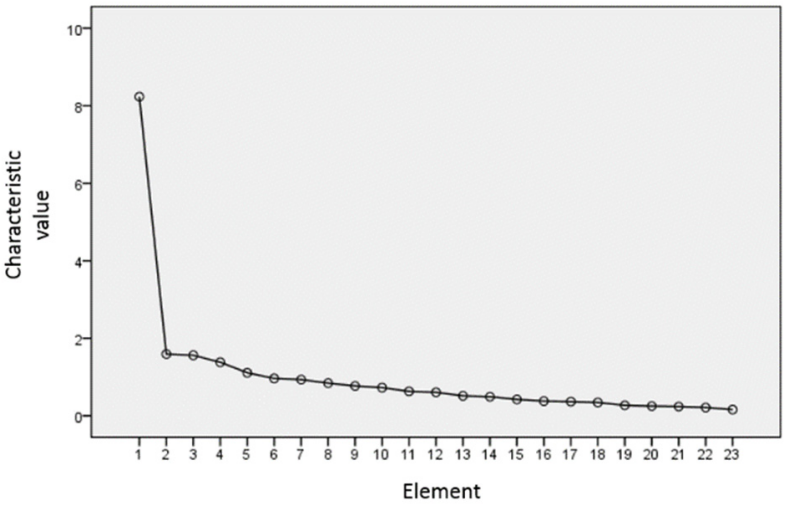

Fig 1. Gravel diagram

It can be seen from the gravel diagram that after the fifth element, the slope line is relatively flat, so it is more appropriate to retain the five elements. A five-element structure model was obtained. The number of feature factors included are 5, 6, 4, 4, and 4 respectively. According to the content of the characteristic elements included in the factors and referring to McNair's naming method, the factors of the port operator's job competency questionnaire (first-level indicator) are named as B1: safety awareness (5 factors), B2: basic qualities (6 factors), and B3: work ability (4 factors), B4: professional skills (4 factors), B5: emergency response capabilities (4 factors). Further calculation and analysis of the correlation between each characteristic element and the factors were carried out. The Pearson product-moment correlation coefficient between the 23 core characteristic elements and each factor and the total score can be obtained, as shown in Table 3.

Table2. Characteristic elements $(\mathrm{n}=281)$

\begin{tabular}{|c|c|}
\hline No. & Safety Competency Characteristic Elements \\
\hline $\mathrm{C}_{11}$ & $\begin{array}{l}\text { Work conscientiously and responsibly, have a strong sense of } \\
\text { responsibility, and be able to do their own work well }\end{array}$ \\
\hline $\mathrm{C}_{12}$ & $\begin{array}{l}\text { Able to adhere to their own safety principles, not being safe and } \\
\text { not producing }\end{array}$ \\
\hline $\mathrm{C}_{13}$ & $\begin{array}{l}\text { Pay attention to self-safety protection, personal protection } \\
\text { compliance }\end{array}$ \\
\hline $\mathrm{C}_{14}$ & $\begin{array}{l}\text { Know the great responsibility of safety, and consciously } \\
\text { improving their safety behaviors }\end{array}$ \\
\hline $\mathrm{C}_{15}$ & $\begin{array}{c}\text { Able to stop unsafe behaviors of workers in time during working } \\
\text { process }\end{array}$ \\
\hline $\mathrm{C}_{21}$ & Good health, able to withstand the work intensity of the job \\
\hline $\mathrm{C}_{22}$ & $\begin{array}{l}\text { Have a strong focus and be able to do single-mindedness at } \\
\text { work }\end{array}$ \\
\hline $\mathrm{C}_{23}$ & Familiar with the tools and tools involved in this position \\
\hline $\mathrm{C}_{24}$ & $\begin{array}{c}\text { Familiar with the types of goods and materials involved in this } \\
\text { post }\end{array}$ \\
\hline $\mathrm{C}_{25}$ & $\begin{array}{c}\text { Able to actively obey the arrangement of the team leader or } \\
\text { leader }\end{array}$ \\
\hline $\mathrm{C}_{26}$ & $\begin{array}{c}\text { Able to suppress negative emotions and stabilize work when } \\
\text { encountering difficulties }\end{array}$ \\
\hline $\mathrm{C}_{31}$ & $\begin{array}{l}\text { Rich work experience, deep understanding of job security, and } \\
\text { unique insights }\end{array}$ \\
\hline $\mathrm{C}_{32}$ & Have strong problem-solving skills \\
\hline $\mathrm{C}_{33}$ & $\begin{array}{c}\text { Strong execution, able to complete the tasks assigned by the } \\
\text { leader in time }\end{array}$ \\
\hline $\mathrm{C}_{34}$ & $\begin{array}{c}\text { Have strong teamwork skills and be able to cooperate } \\
\text { effectively }\end{array}$ \\
\hline $\mathrm{C}_{41}$ & Master the operation skills required for the post, and be skilled \\
\hline $\mathrm{C}_{42}$ & Master the safety skills and knowledge required for the job \\
\hline $\mathrm{C}_{43}$ & Pass professional training and hold a certificate \\
\hline $\mathrm{C}_{44}$ & $\begin{array}{l}\text { Consciously comply with the requirements of the safety system, } \\
\text { operating procedures and other requirements }\end{array}$ \\
\hline
\end{tabular}

\begin{tabular}{|c|c|}
\hline $\mathrm{C}_{51}$ & $\begin{array}{c}\text { Strong hazard identification, risk management and control } \\
\text { capabilities }\end{array}$ \\
\hline $\mathrm{C}_{52}$ & $\begin{array}{c}\text { Familiar with equipment performance, and have the ability to } \\
\text { inspect and judge equipment failures }\end{array}$ \\
\hline $\mathrm{C}_{53}$ & $\begin{array}{c}\text { Have quick response, able to deal with emergencies quickly and } \\
\text { decisively }\end{array}$ \\
\hline $\mathrm{C}_{54}$ & Possess good job-hidden hazard investigation capabilities \\
\hline
\end{tabular}

Table3. Pearson product-moment correlation coefficient between each factor and the total score

\begin{tabular}{|c|c|c|c|c|c|c|}
\hline & B1 & B2 & B3 & B4 & B5 & $\begin{array}{l}\text { Total } \\
\text { score }\end{array}$ \\
\hline B1 & 1 & 0.598 & 0.635 & 0.554 & 0.411 & 0.896 \\
\hline $\mathrm{C}_{11}$ & 0.751 & 0.342 & 0.407 & 0.479 & 0.27 & 0.638 \\
\hline $\mathrm{C}_{12}$ & 0.759 & 0.452 & 0.396 & 0.435 & 0.225 & 0.647 \\
\hline $\mathrm{C}_{13}$ & 0.787 & 0.641 & 0.557 & 0.456 & 0.428 & 0.781 \\
\hline $\mathrm{C}_{14}$ & 0.564 & 0.301 & 0.289 & 0.31 & 0.181 & 0.471 \\
\hline $\mathrm{C}_{15}$ & 0.638 & 0.481 & 0.35 & 0.263 & 0.348 & 0.55 \\
\hline B2 & 0.598 & 1 & 0.558 & 0.494 & 0.488 & 0.804 \\
\hline $\mathrm{C}_{21}$ & 0.268 & 0.584 & 0.27 & 0.22 & 0.191 & 0.452 \\
\hline $\mathrm{C}_{22}$ & 0.366 & 0.64 & 0.399 & 0.27 & 0.272 & 0.5 \\
\hline $\mathrm{C}_{23}$ & 0.435 & $\mathbf{0 . 7 8 7}$ & 0.347 & 0.367 & 0.423 & 0.599 \\
\hline $\mathrm{C}_{24}$ & 0.428 & 0.796 & 0.419 & 0.449 & 0.457 & 0.637 \\
\hline $\mathrm{C}_{25}$ & 0.442 & 0.725 & 0.481 & 0.409 & 0.257 & 0.597 \\
\hline $\mathrm{C}_{26}$ & 0.314 & 0.707 & 0.19 & 0.197 & 0.421 & 0.441 \\
\hline B3 & 0.635 & 0.558 & 1 & 0.444 & 0.346 & 0.781 \\
\hline $\mathrm{C}_{31}$ & 0.399 & 0.322 & 0.739 & 0.17 & 0.274 & 0.497 \\
\hline $\mathrm{C}_{32}$ & 0.575 & 0.468 & 0.825 & 0.381 & 0.34 & 0.68 \\
\hline $\mathrm{C}_{33}$ & 0.415 & 0.402 & 0.708 & 0.444 & 0.116 & 0.543 \\
\hline $\mathrm{C}_{34}$ & 0.55 & 0.519 & 0.799 & 0.391 & 0.306 & 0.672 \\
\hline B4 & 0.554 & 0.494 & 0.444 & 1 & 0.313 & 0.711 \\
\hline $\mathrm{C}_{41}$ & 0.408 & 0.282 & 0.252 & 0.773 & $.180^{*}$ & 0.486 \\
\hline $\mathrm{C}_{42}$ & 0.239 & 0.276 & 0.32 & 0.682 & 0.275 & 0.426 \\
\hline $\mathrm{C}_{43}$ & 0.407 & 0.363 & 0.312 & 0.788 & 0.248 & 0.533 \\
\hline $\mathrm{C}_{44}$ & 0.636 & 0.588 & 0.477 & 0.811 & 0.255 & 0.727 \\
\hline B5 & 0.411 & 0.488 & 0.346 & 0.313 & 1 & 0.608 \\
\hline $\mathrm{C}_{51}$ & 0.329 & 0.407 & 0.502 & 0.349 & 0.763 & 0.664 \\
\hline $\mathrm{C}_{52}$ & 0.318 & 0.427 & 0.465 & 0.4 & 0.665 & 0.627 \\
\hline $\mathrm{C}_{53}$ & 0.2 & 0.369 & 0.518 & 0.461 & 0.668 & 0.618 \\
\hline $\mathrm{C}_{54}$ & 0.379 & 0.476 & 0.517 & 0.37 & 0.687 & 0.664 \\
\hline $\begin{array}{l}\text { Total } \\
\text { score } \\
\end{array}$ & 0.896 & 0.804 & 0.781 & 0.711 & 0.608 & 1 \\
\hline
\end{tabular}

It can be seen from Table 3 that the correlation coefficient between each factor is significant at the level of 0.01 , the correlation coefficient between the total score and each factor is also significant at the level of 0.01 , and the correlation coefficient value between each characteristic element and the corresponding factor is universally higher than 0.5 , which shows that the discriminating power of the 23 core feature elements is relatively good, and the internal consistency and relevance are good. Therefore, it has good content validity.

\subsection{Analysis of overall reliability of port operators' job safety competencies}

An internal consistency coefficient $\alpha$ coefficient proposed by Cronbach accurately reflects the consistency of the characteristic elements and the goodness of the internal structure. Therefore, this paper used this method to assess 
the overall reliability of the job safety competency system. Cronbach's $\alpha$ coefficient calculation formula is as follows:

$$
\alpha=\frac{k \bar{r}}{1+(k-1) \bar{r}}
$$

In the formula, $k$ is the number of items included in the questionnaire. When the questionnaire contains several sub-questions, $k$ is the number of items in the subscale; $\bar{r}$ is the mean value of the correlation coefficients of $k$ items, and Cronbach's $\alpha$ coefficient is between 0 and 1 . Calculating the obtained 281 valid statistical data, the overall reliability is 0.916 , indicating that the core feature element has a high inherent reliability.

\section{Fuzzy Comprehensive Evaluation of Post Safety Competency}

Fuzzy comprehensive evaluation method is a comprehensive evaluation method that uses the principle of fuzzy mathematics and follows the maximum degree of membership theory to carry out a comprehensive evaluation method for objects that are simultaneously affected by multiple factors. The result of fuzzy comprehensive evaluation is clear and systematic. It is especially suitable for solving various complex problems that are fuzzy and not easy to be directly quantified.

According to the safety requirements of key positions, this paper carried out multi-level fuzzy comprehensive evaluation, constructed the subordination grade evaluation criteria of port job operations, established a matrix model of multi-level safety fuzzy evaluation, and formed the theoretical system and analysis method of fuzzy comprehensive safety evaluation of safety competence of the post, and the fuzzy comprehensive evaluation was used for the third-level index, second-level index and first-level index successively, so that the comprehensive evaluation results of each level can be obtained respectively, and the job safety quality and job competence of the workers can be quantitatively evaluated.

\subsection{Index weight calculation}

Due to its objectiveness and rationality, entropy weight method has been widely used in the fields of engineering technology, social economy and environmental science. Therefore, this study was based on the theoretical analysis method of system dynamics objective weighting, using the information entropy of the sample population of key positions to calculate the entropy weight of each level of assessment indicators, and then it used the entropy value to modify the weight of each level of assessment indicators, constructing an objective and scientific weight model.

The specific method is as follows:

There are $m$ items to be evaluated (personnel) and $n$ evaluation indicators to form the original evaluation matrix

$$
\mathrm{R}=\left(\mathrm{r}_{i j}\right)_{m \times n}
$$

For a certain index $n_{j}(j=1, n)$, there is information entropy:

$$
\mathrm{e}_{j}=-\sum_{i=1}^{m} \mathrm{p}_{i j} \cdot \ln \mathrm{p}_{i j}, \mathrm{p}_{i j}=\mathrm{r}_{i j} / \sum_{i=1}^{m} \mathrm{r}_{i j}
$$

According to information entropy:

$$
\mathrm{D}_{j}=1-\mathrm{e}_{j} / \ln (\mathrm{m})
$$

Available index weights:

$$
\mathrm{W}_{j}=\mathrm{D}_{j} / \sum_{j=1}^{n} \mathrm{D}_{j}
$$

Taking terminal loading and unloading operators as an example, the index weights of five secondary indicators of terminal loading and unloading operators can be obtained through the entropy method and normalized calculation:

Table4. The weight factor of 5 secondary index for wharf stevedores

\begin{tabular}{|c|c|}
\hline Secondary indicators & Weights \\
\hline Safety consciousness & 0.1581 \\
\hline Basic Quality & 0.2463 \\
\hline Work Ability & 0.1581 \\
\hline Professional skill & 0.1872 \\
\hline Emergency capability & 0.2503 \\
\hline
\end{tabular}

The original evaluation matrix and index weight of 23

\begin{tabular}{|c|c|}
\hline Third grade index & Weights \\
\hline $\begin{array}{l}\text { Work conscientiously and responsibly, have a strong sense of } \\
\text { responsibility, and be able to do their own work well }\end{array}$ & 0.0133 \\
\hline $\begin{array}{c}\text { Able to adhere to their own safety principles, not being safe } \\
\text { and not producing }\end{array}$ & 0.0133 \\
\hline $\begin{array}{l}\text { Pay attention to self-safety protection, personal protection } \\
\text { compliance }\end{array}$ & 0.0324 \\
\hline $\begin{array}{l}\text { Know the great responsibility of safety, and consciously } \\
\text { improving their safety behaviors }\end{array}$ & 0.0242 \\
\hline $\begin{array}{c}\text { The work process can stop unsafe behaviors of workers in } \\
\text { time }\end{array}$ & 0.0286 \\
\hline Good health, able to withstand the work intensity of the job & 0.2087 \\
\hline $\begin{array}{l}\text { Have a strong focus and be able to do single-mindedness at } \\
\text { work }\end{array}$ & 0.0579 \\
\hline Familiar with the tools and tools involved in this position & 0.0286 \\
\hline $\begin{array}{l}\text { Familiar with the types of goods and materials involved in } \\
\text { this post }\end{array}$ & 0.0377 \\
\hline $\begin{array}{c}\text { Able to actively obey the arrangement of the team leader or } \\
\text { leader }\end{array}$ & 0.0286 \\
\hline $\begin{array}{c}\text { Able to suppress negative emotions and stabilize work when } \\
\text { encountering difficulties }\end{array}$ & 0.0691 \\
\hline $\begin{array}{l}\text { Rich work experience, deep understanding of job security, } \\
\text { and unique insights }\end{array}$ & 0.0691 \\
\hline Have strong problem-solving skills & 0.0529 \\
\hline $\begin{array}{l}\text { Strong execution, able to complete the tasks assigned by the } \\
\text { leader in time }\end{array}$ & 0.0397 \\
\hline $\begin{array}{c}\text { Have strong teamwork skills and be able to cooperate } \\
\text { effectively }\end{array}$ & 0.0191 \\
\hline $\begin{array}{l}\text { Master the operation skills required for the post, and be } \\
\text { skilled }\end{array}$ & 0.0191 \\
\hline Master the safety skills and knowledge required for the job & 0.0191 \\
\hline Pass professional training and hold a certificate & 0.0242 \\
\hline $\begin{array}{l}\text { Consciously comply with the requirements of the safety } \\
\text { system, operating procedures and other requirements }\end{array}$ & 0.0324 \\
\hline $\begin{array}{l}\text { Strong hazard identification, risk management and control } \\
\text { capabilities }\end{array}$ & 0.0324 \\
\hline $\begin{array}{l}\text { Familiar with equipment performance, and have the ability to } \\
\text { inspect and judge equipment failures }\end{array}$ & 0.0354 \\
\hline $\begin{array}{l}\text { Have quick response, able to deal with emergencies quickly } \\
\text { and decisively }\end{array}$ & 0.0558 \\
\hline Possess good job-hidden hazard investigation capabilities & 0.0587 \\
\hline
\end{tabular}
three-level indicators can be obtained by using the same method:

Table5. The weight factor of 23 three-level index for wharf stevedores

As calculated above, the weights of the second-level and third-level indicators in the post-safety competency evaluation index system of terminal loading and unloading operators can be obtained. 


\subsection{Fuzzy comprehensive evaluation}

The factor set $U=\left\{\mathrm{u}_{1}, \mathrm{u}_{2}, \ldots, \mathrm{u}_{\mathrm{n}}\right\}$, where $\mathrm{u}_{1}, \mathrm{u}_{2}, \ldots \mathrm{u}_{\mathrm{n}}$ are the evaluation indicators, and $\mathrm{n}$ is the number of indicators at the same level. According to the post safety competency evaluation index system constructed in this paper, the index set $U$ is divided into a three-level index set. Evaluation set $\mathrm{V}=\left\{\mathrm{v}_{1}, \mathrm{v}_{2}, \ldots, \mathrm{v}_{\mathrm{m}}\right\}$, where $\mathrm{V}_{\mathrm{j}}(\mathrm{j}=1,2, \ldots, \mathrm{m})$ is the possible evaluation result, and $\mathrm{m}$ is the number of possible evaluation results. The weight set $A=\left(a_{1}, a_{2}, \ldots\right.$, $\left.a_{n}\right)$, where $a_{i}(i=1,2, \ldots, n)$ is the weight value of each indicator in the factor set $U$, and $n$ is the number of indicators in $U$. $a_{i}$ represents the importance of each indicator in the indicator system, and generally conforms to normalization and non-negativity:

$$
\sum_{i=1}^{n} a_{i}=1 \text {, Where } 0 \leq a_{i} \leq 1(i=1,2, \ldots n)
$$

Based on the evaluation criteria, the third-level indicators are evaluated according to the actual situation of the operators, and the evaluation results are obtained, which is the fuzzy evaluation matrix of the three-level indicators.

Taking the evaluation of the factor $\mathrm{u}_{\mathrm{i}}$ as an example, its membership of the $\mathrm{j}$-th element $\mathrm{v}_{\mathrm{j}}$ is $\mathrm{r}_{\mathrm{ij}}$, then:

$$
R\left(u_{i}\right)=\left\{r_{i 1}, r_{i 2}, \ldots, r_{i m}\right\}
$$

$\mathrm{R}\left(\mathrm{u}_{\mathrm{i}}\right)$ represents the evaluation level set of the factor, which is a fuzzy subset of the evaluation level set V. According to the fuzzy evaluation of other factors carried out above, finally the fuzzy evaluation grade matrix $\mathrm{R}=\mathrm{UV}$ is obtained.

$$
R=\left[\begin{array}{cccc}
r_{11} & r_{12} & \ldots & r_{1 m} \\
r_{21} & r_{22} & \ldots & r_{2 m} \\
\ldots & \ldots & & \ldots \\
r_{n 1} & r_{n 2} & \ldots & r_{n m}
\end{array}\right]
$$

That is, the factor membership matrix is multiplied by the weight set.

$$
\mathrm{B}=\mathrm{A} R=\left(a_{1}, a_{2}, \ldots, a_{n}\right)\left[\begin{array}{cccc}
r_{11} & r_{12} & \ldots & r_{1 m} \\
r_{21} & r_{22} & \ldots & r_{2 m} \\
\ldots & \ldots & \ldots & \ldots \\
r_{n 1} & r_{n 2} & \ldots & r_{n m}
\end{array}\right]=\left(b_{1}, b_{2}, \ldots, b_{m}\right)
$$

$b_{i}$ is called the fuzzy comprehensive evaluation result of job safety competence, and is normalized:

$$
b_{j}=b_{j} / \sum_{j=1}^{m} b j
$$

The standard evaluation result can be obtained:

$$
B^{\prime}=\left(b_{1}{ }^{\prime}, b_{2}{ }^{\prime}, \ldots, b_{m}{ }^{\prime}\right)
$$

Based on this, the fuzzy comprehensive evaluation is performed on each layer respectively, and finally the final fuzzy comprehensive evaluation result is obtained, and then normalized. Finally, according to the principle of maximum degree of membership, the evaluation grade of the evaluation object is obtained, and the conclusion of this evaluation is given.

According to the responsibilities of terminal stevedores and the evaluation index system, the terminal

\begin{tabular}{|c|c|c|c|c|c|c|c|}
\hline \multirow[b]{2}{*}{$\begin{array}{c}\text { Evaluation index } \\
\text { number }\end{array}$} & \multicolumn{7}{|c|}{ Evaluation object } \\
\hline & $\begin{array}{c}A A \\
1\end{array}$ & $\begin{array}{c}A A \\
2\end{array}$ & $\begin{array}{c}A A \\
3\end{array}$ & $\begin{array}{c}A \boldsymbol{A} \\
4\end{array}$ & $\begin{array}{c}A A \\
5\end{array}$ & $\begin{array}{c}A A \\
6\end{array}$ & $\begin{array}{c}\boldsymbol{A A} \\
7\end{array}$ \\
\hline $\mathrm{C}_{11}$ & 8 & 7 & 8 & 7 & 9 & 9 & 8 \\
\hline $\mathrm{C}_{12}$ & 9 & 8 & 9 & 9 & 9 & 9 & 10 \\
\hline $\mathrm{C}_{13}$ & 9 & 7 & 9 & 10 & 8 & 8 & 9 \\
\hline $\mathrm{C}_{14}$ & 8 & 7 & 10 & 10 & 9 & 10 & 10 \\
\hline $\mathrm{C}_{15}$ & 9 & 8 & 10 & 8 & 8 & 8 & 10 \\
\hline $\mathrm{C}_{21}$ & 8 & 9 & 10 & 8 & 10 & 8 & 9 \\
\hline $\mathrm{C}_{22}$ & 8 & 7 & 10 & 10 & 8 & 8 & 10 \\
\hline $\mathrm{C}_{23}$ & 9 & 8 & 9 & 10 & 9 & 10 & 8 \\
\hline $\mathrm{C}_{24}$ & 9 & 8 & 10 & 9 & 9 & 9 & 9 \\
\hline $\mathrm{C}_{25}$ & 8 & 7 & 10 & 9 & 9 & 10 & 10 \\
\hline $\mathrm{C}_{26}$ & 8 & 8 & 10 & 9 & 9 & 8 & 10 \\
\hline $\mathrm{C}_{31}$ & 8 & 8 & 8 & 9 & 8 & 9 & 8 \\
\hline $\mathrm{C}_{32}$ & 9 & 8 & 10 & 9 & 9 & 8 & 9 \\
\hline $\mathrm{C}_{33}$ & 8 & 7 & 10 & 9 & 8 & 9 & 10 \\
\hline $\mathrm{C}_{34}$ & 8 & 7 & 10 & 10 & 8 & 9 & 10 \\
\hline $\mathrm{C}_{41}$ & 7 & 8 & 9 & 10 & 7 & 7 & 8 \\
\hline $\mathrm{C}_{42}$ & 8 & 7 & 10 & 9 & 8 & 8 & 8 \\
\hline $\mathrm{C}_{43}$ & 10 & 10 & 10 & 10 & 10 & 10 & 10 \\
\hline $\mathrm{C}_{44}$ & 8 & 8 & 10 & 9 & 9 & 10 & 10 \\
\hline $\mathrm{C}_{51}$ & 8 & 8 & 7 & 10 & 9 & 9 & 7 \\
\hline $\mathrm{C}_{52}$ & 7 & 8 & 7 & 9 & 8 & 8 & 7 \\
\hline $\mathrm{C}_{53}$ & 9 & 9 & 9 & 8 & 8 & 9 & 7 \\
\hline $\mathrm{C}_{54}$ & 9 & 8 & 10 & 9 & 9 & 8 & 9 \\
\hline
\end{tabular}
stevedores of a domestic port group were evaluated. The third-level indicators, second-level indicators and job safety competency scores are as follows.

Table6. Matching score of the three-level index for wharf stevedores (full score is 10 for each item)

The scores of the second-level indicators can be obtained by multiplying the weights of the third-level

\begin{tabular}{|c|c|c|c|c|c|c|c|}
\hline \multirow[b]{2}{*}{ Evaluation index number } & \multicolumn{7}{|c|}{ Evaluation object } \\
\hline & $A A 1$ & $A A 2$ & $\boldsymbol{A} \boldsymbol{A 3}$ & $A A 4$ & $A A 5$ & AA6 & $A A 7$ \\
\hline B1 & 86.65 & 73.75 & 93.53 & 90.12 & 84.54 & 86.71 & 94.72 \\
\hline $\mathrm{B} 2$ & 81.54 & 82.84 & 99.34 & 87.16 & 93.50 & 83.53 & 92.95 \\
\hline B3 & 82.93 & 76.75 & 92.36 & 91.05 & 82.93 & 87.07 & 89.43 \\
\hline B4 & 83.09 & 83.09 & 97.99 & 94.57 & 86.51 & 89.93 & 91.95 \\
\hline B5 & 84.34 & 83.06 & 85.79 & 88.71 & 85.00 & 84.84 & 76.44 \\
\hline
\end{tabular}
indicators by the membership degree matrix of the thirdlevel indicators, and normalize the scores, each of which has a full score of 100 points, as shown in the following table.

Table7. Matching score of the secondary index for wharf stevedores

By further multiplying the weight of the secondary index by the membership matrix of the secondary index, the score of the safety competence of dock stevedores can be obtained and normalized, with a full score of 100 points, as shown in the table below. 
Table8. Post safety competence score of the wharf stevedores

\begin{tabular}{|c|c|c|c|c|c|c|c|}
\hline \multirow{2}{*}{$/$} & \multicolumn{7}{|c|}{ Evaluation object } \\
\cline { 2 - 8 } & $\boldsymbol{A A 1}$ & $\boldsymbol{A A 2}$ & $\boldsymbol{A A 3}$ & $\boldsymbol{A A 4}$ & $\boldsymbol{A A 5}$ & $\boldsymbol{A A 6}$ & $\boldsymbol{A A 7}$ \\
\hline Score & 83.56 & 80.54 & 93.67 & 90.02 & 86.98 & 86.12 & 88.35 \\
\hline
\end{tabular}

From this, we can obtain the value of the safety competence of the stevedores at the terminal.

It can be seen from the evaluation results that among the 7 employees, the highest score is 93.67 , and the lowest score is 80.54 . Two objects are excellent (above 90), and five are good (80-89).

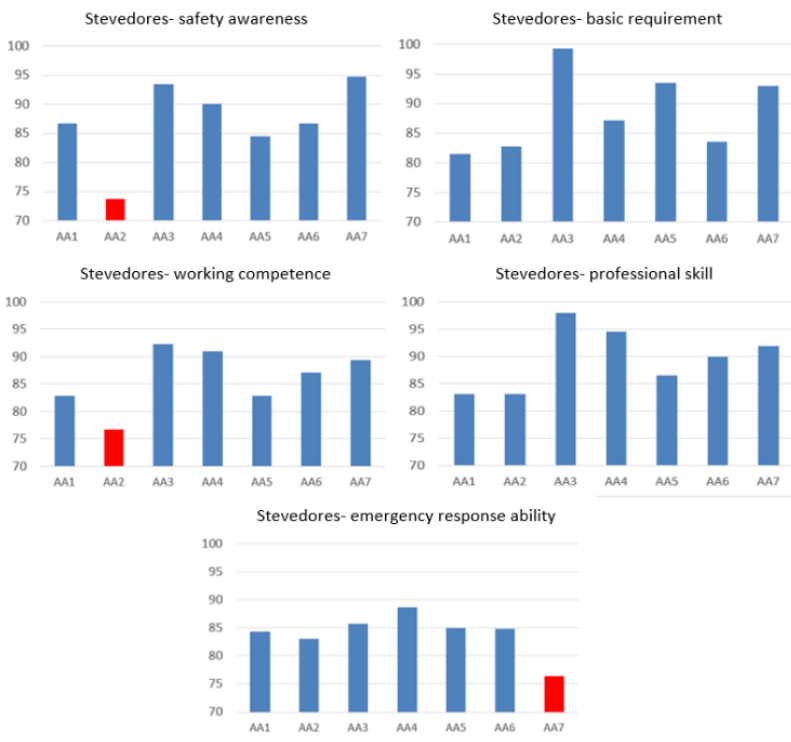

Fig 2. Analysis on the score of secondary index of wharf stevedores

It can be seen that the operator with the lowest score of AA2 loses points in terms of safety awareness and working competence. The matching scores of these two elements are both below 80 points. It can be seen that this operator needs to strengthen safety awareness and work. In terms of ability learning, although the total score of AA7 of the operators is high, their emergency response ability score is low, less than 80 points. Therefore, it is necessary to strengthen the learning of emergency ability to improve the safety and competence of the terminal stevedores.

\section{Conclusion}

This study conducted a more systematic study on the port operator's job competency evaluation indicators. By using the port operator's job safety competency questionnaire compiled for verification, statistical analysis and exploratory factor analysis were performed on the collected valid sample data to determine the port $23 \mathrm{key}$ characteristic elements of job competence of operators, principal component analysis of these 23 items, clarified 5-element structure model, and named the 5 port operator job competency factors (first-level indicators) as safety awareness, basic quality, work ability, professional skills, emergency response ability.

The objective weighting method was used to calculate the entropy weight of each level of assessment indicators based on the information entropy of the sample population of key positions. Based on the key job responsibilities, the weight of each level of assessment indicators is revised through entropy weight to construct an objective and scientific weight matrix. On this basis, according to the safety requirements of key positions, a multi-level fuzzy theory comprehensive evaluation was carried out to quantitatively evaluate the safety quality and competence of the workers. In accordance with the evaluation results of the job safety competencies of the workers, the weaknesses can be clarified to improve their job safety competencies. It can be said that this method not only solved the technical problem of job safety competency evaluation of port industry workers for the first time in China, but also laid a theoretical foundation for the safety and competence evaluation of subsequent job workers.

\section{Acknowledgment}

The research is supported by the special fund for the basic research business of the central public welfare research institutes (TKS20200320, TKS190108, TKS190111) and 2020 key science and technology projects of transportation industry (2020-MS3-097).

\section{References}

1. R. E. Boyatzis, The international civil aviation organization. Safety Management, Hoboken, NewJersey: John Wiley\&Sons, 2016.

2. R. E. Boyatzis, The competent manager: A model for effective performance, Hoboken, NewJersey: John Wiley\&Sons, 1982.

3. W. W. Yan, W. H. Zhang, L. Wang, and G.H. Chen, Present status of quality of safety personnel in enterprises and suggestions on their training, China Safety Science Journal, 2006, 16(10), pp.51-55.

4. F. Chen and Y. Luo, Study on competency model of quality \& safety supervisors in air traffic management department of civil aviation, Journal of Safety Science and Technology, 2011, 7(12), pp.140-144.

5. H. Sadeghi, M. Y. Mousakhani, M. Yazdani, and M. Delavari, Evaluating project managers by an interval decision-making method based on a new project manager competency model, Arabian Journal for Science \& Engineering, 2014, 39(2) , pp.1417-1430.

6. H. H. Xu, Y. H. Wang, Training system design for middle-level manager in coal enterprises based on post competency model, Procedia Earth \& Planetary Science, 2009, 1(1), pp.1764-1771.

7. J. S. Shippmann, R. A. Ash, M. Batjtsta, L. Carr, and J. I. Sanchez, The practice of competency modeling, Personnel Psychology, 2000, 53(3), pp.703-740.

8. S. Zhou, Study on capability maturity model for safety management of electric power production team, 
Journal of Safety Science and Technology, 2012, 8(4), pp.161-165.

9. W. Y. Yu and W. Zhang, Development of competency model of manufacturing safety managers, Journal of Safety Science and Technology, 2011,7(7), pp.133-137.

10. C. Liu, S. C. Tian, and J. Liu, Assessment for Safety Capability of Team Leader in Coal Mine Based on AHP and GRA, Safety in Coal Mines, 2014, 45(10), pp.245-248.

11. K. Park and H. Song, Job competency analysis for construction site safety manager-focused on the engineering \&construction Company, Korea Crisis Management Directory, 2000(11), pp.10-11.

12. Y. L. Wang, Q. Mei, and S. X. Liu, Research on both competency structure of safety manager in SMEs and its reliability and validity, China Safety Science Journal, 2016, 26 (7) , pp.152-156.

13. F. Chen, N. Guo, and S. S. Han, Empirical study on competency model of safety management personnel in civil aviation operation organizations, Journal of Safety Science and Technology, 2018, 14 (6) , pp.165-170.

14. N.W. Li and Z. J. Zhang, Study on Post Safety Competency Model of Special Operation Personnel in Coal Enterprise, China Safety Science Journal, 2008, 18(1), pp.14-19.

15. Z. Y. Lin, Human accident prevention, Harbin: Heilongjiang Education Press, 1998.

16. G. G. Xiao and B.Z., Chen Study on the mechanism of human error and its reliability. China Safety Science Journal, 2001,11 (1) , pp.22-25.

17. N.W. Li and Zheng Y. H. Discussion on Miners' Job Stress and Its Counter measures, China Safety Science Journal, 2007, 17(6) , pp.43-47.

18. B. Z. Chen, Safety Principle, Beijing: Metallurgical Industry Press, 1995.

19. L. M. Spence and D. C. McClelland, Competency assessment methods: History and state of the art, Boston: Hay-McBer Research Press, 1994.

20. L. F. Zhong and K. Shi, The New Development of the Research of Competencies, NANKAI BUSINESS REVIEW, 2003(2), pp.4-7.

21. J. F. Wang and W. J. Li, China's coal mine accidents and expert comments, Beijing: Coal Industry Press, 2001. 